$$
\begin{aligned}
& \text { معرفى Cousinia elymaitica (تيره كاسنيان) به عنوان Fونه جديد از غرب ايران }
\end{aligned}
$$

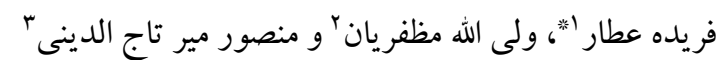

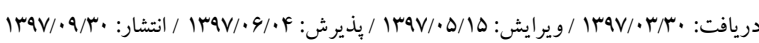

$$
\begin{aligned}
& \text { 'هرباريوم مر كزى دانشگاه تهران، دانشكده زيست شناسى، يرديس علوم، دانشكاه تهر ان، تهر ان، ايران }
\end{aligned}
$$

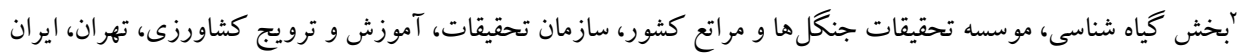

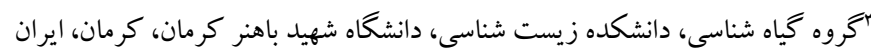

مسئول مكاتبات: fattar@ khayam.ut.ac.ir

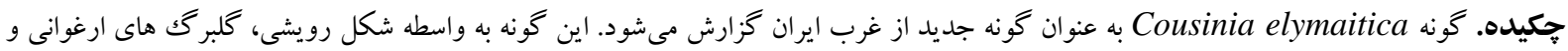

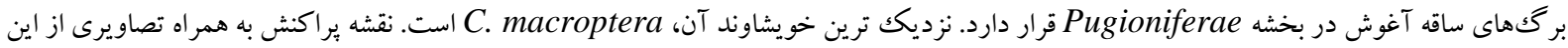

$$
\text { كونه ار ائه شده است. }
$$

$$
\text { وازههاى كليدى. آرايه جديد. آسيا، انحصارى، تيره مر كبان، فلور ايران }
$$

\title{
Cousinia elymaitica (Cardueae, Asteraceae) a new species from west of Iran
}

\author{
Farideh Attar ${ }^{*}$, Valiollah Mozaffarian ${ }^{2} \&$ Mansour Mirtadzadini $^{3}$ \\ Received: 20.06.2018 / Revised: 06.08.2018 / Accepted: 26.08.2018 / Published: 21.12.2018
}

\begin{abstract}
${ }^{1}$ Central Herbarium of Tehran University, School of Biology, College of Science, University of Tehran, Tehran, Iran ${ }^{2}$ Research Institute of Forests and Rangelands, Agricultural Research, Education and Extension Organization (AREEO), Tehran, Iran

${ }^{3}$ Department of Biology, Faculty of Science, Shahid Bahonar University of Kerman, Kerman, Iran

${ }^{*}$ Correspondent author: fattar@khayam.ut.ac.ir
\end{abstract}

\begin{abstract}
Cousinia elymaitica, which has been collected from western Iran, is described in this paper as a new species. This new species has been assigned to the sect. Pugioniferae on the basis of its habit, purple corolla and decurrent leaves. Its closest related species is $C$. macroptera. A distribution map and an illustration of the related specimens have also been provided.
\end{abstract}

Keywords. Asia, Compositae, endemic, flora of Iran, new taxon

\section{INTRODUCTION}

Cousinia Cass. is the third largest genus of the family Compositae with approximately 700 species in the world (Attar \& Ghahreman, 2006; Attar \& Djavadi, 2010). A large number of Cousinia species are distributed in the Irano-Turanian region. Cousinia is artificially divided into 43 sections (Attar \& Djavadi, 2010) in Iran. The largest section is Cynaroides Bunge with 75 species and the smallest sections are Decumbentes Rech.f. and Harazensis Rech.f., each with only one species.
During collections of Cousinia specimens in the last 20 years, an interesting specimen was found from the west of Iran, beeing described as new species here. Cousinia elymaitica is related to the sect. Pugioniferae Bunge by having purple corolla, winged stems, smooth bristles, spreading phyllaries and large basal leaves. Section Pugioniferae has 15 species (Rechinger, 1972; Attar \& Mirtadzadini 2009; Assadi, 2009) of which 13 taxa are distributed in Iran. 

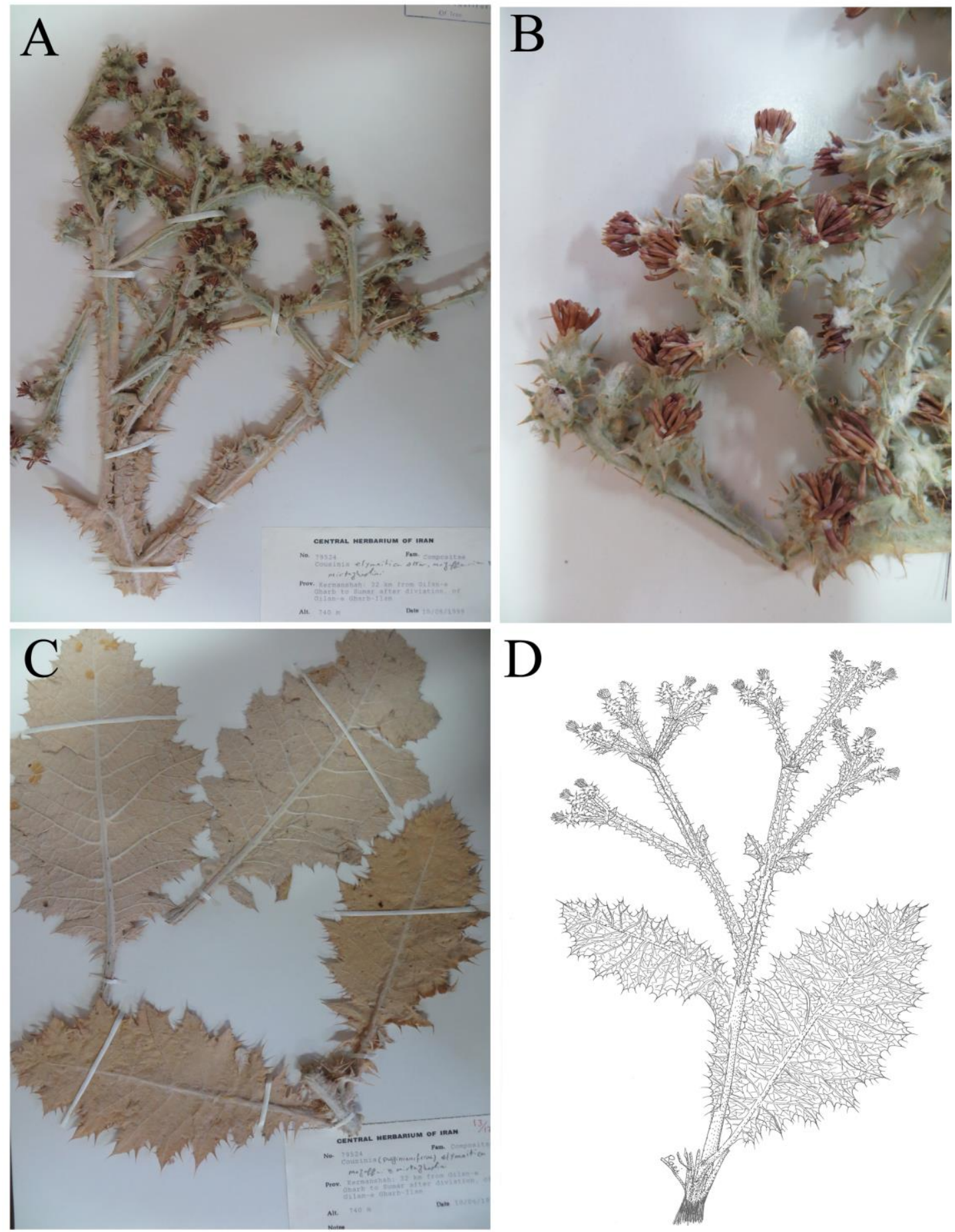

Fig. 1. A-D: Photos and Illustration of Cousinia elymaitica, from holotype (Mozaffarian 79524).

The related taxon to the new species is $C$. macroptera, which is distributed in NW Iran, E Turkey, and S Transcaucasus.

\section{MATERIALS AND METHODS}

During the study of about 100 specimens of section Pugioniferae collected deposited in TUH and TARI, an interesting specimen was found which could not be assigned to previously known species of this section in Iran. Therefore, this specimen is introduced as the new species for the science.

\section{RESULTS AND DISCUSSION}

Cousinia elymaitica Attar, Mozaff. \& Mirtadz., sp. nova (Fig. 1. A-D). 

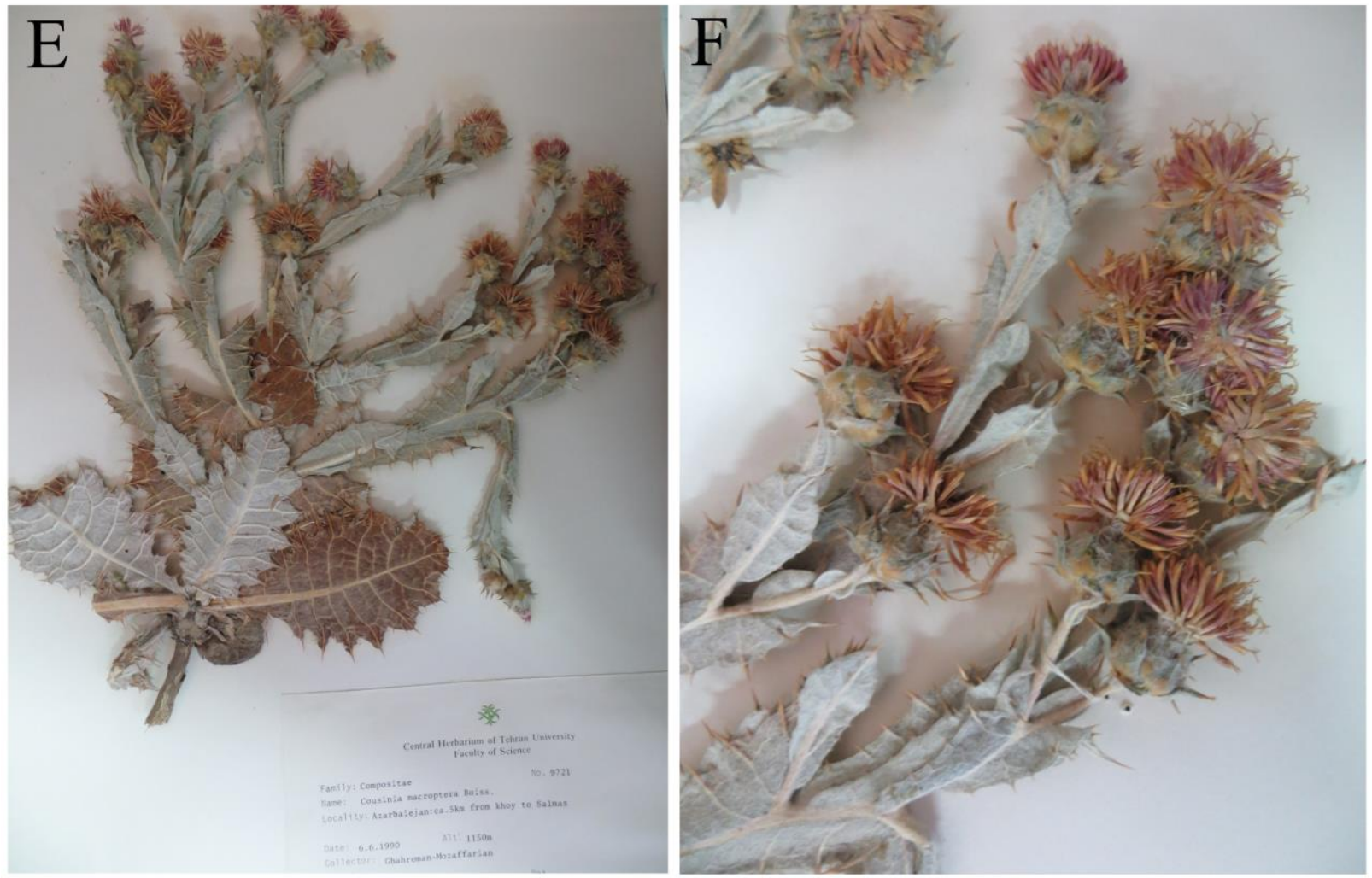

Fig. 2. E-F: Photos of Cousinia macroptera.

Holotype: Kermanshah Province: $32 \mathrm{~km}$ from Gilan-e Gharb toward Sumar, after division of Gilan-e Gharb and Ilam, 740 m, 10.6.1999, Mozaffarian 79524 (TARI).

Description: Monocarpic, up to $35 \mathrm{~cm}$ high, whitearaneose. Stem corymbose above, continuously winged. Leaves more or less discolored, whitish below, broadly lobed, with spines up to $5 \mathrm{~mm}$ long; midrib broad, prominent; lower leaves broad elliptic, 18-24×10-12 cm; cauline leaves decurrent, forming decurrent lobed-spinose wings. Capitula 16 $\mathrm{mm}$ in diam. (including bracts), more or less 20flowered, densely araneose; involucre ovate, constricted above, more or less with 40 phyllaries; bracts ovate, attenuate toward apex, acute; outer and median bracts spreading; inners erect; bristles smooth. Corolla purple, 11-12 mm long; limb 6-7 $\mathrm{mm}$ long; lobes 2-3 mm long; anther tube concolered. Achene brown, obovate, longitudinally memranose-striate, membranous-dentate above, shallowly rugose; pappus caducous

Diagnosis: Differs from C. macroptera in following characters: size of capitulum $(6-8 \mathrm{~mm}$ not $8-10$ $\mathrm{mm}$ ); flower number (15-25 not 50); leaf color (indistinctly discolored not distinctly discolored); bract tip (acute, not spiny), stem wing width (narrow oblong-continue, not wide, attenuate toward base) (Figs. A-D).
Diagnose: Differt ab C. macroptera: capitulum 6-8 $\mathrm{mm}$ (non 8-10 mm), flores 15-25 (non 50), folia indistincte discoloria (non distinct discoloria), apex bracteae acutae (non spinosae), alae caulium continue anguste oblongarum (non basin versus late attenuatarum).

Taxonomic remarks: Cousinia elymaitica belongs to the sect. Pugioniferae by smooth bristles, color of corolla, decurrent leaves and exappendiculate spreading bracts. Cousinia macroptera, by having large oval rosette leaves, capitulum shape and bracts, is the characteristic species among the other members of the section. The new species can be compared with $C$. macroptera, which is presented in NW Iran. Although the type locality of the new species is far from the distribution area of $C$. macroptera, it is close to $C$. macroptera by having large rosette leaves, similar size and shape of bracts and large basal leaves (Figs. E and F). The new species is separated from C. macroptera by the size of capitulum, the number of flowers, the color of basal leaves and stem leaves.

\section{CONCLUSION}

Cousinia, as the second largest genus of Iran flora, consists of several complex species and unidentified taxa. More comprehensive morpholoigical, micromorphological and molecular 
approaches are needed for identification and delimitation of these taxa.

\section{ACKNOLEDGMENT}

Authors should thank Dr. Asghar Zamani for preparation of photos and some corrections of the text.

\section{REFERENCES}

Assadi, M. 2009. Four new species of the genus Cousinia Cass. (Asteraceae) from Iran. - Iran. J. Bot. 15: $36-44$

Attar, F. and Ghahreman, A. 2006. A synopsis of sect. Cynaroides (Cousinia, Compositae), distribution, patterns and diversity centers. - Rostaniha 7: 315342.

Attar, F. and Djavadi, S.B. 2010. A Taxonomic revision of Cousinia, Sect. Cynaroides (Asteraceae, Cardueae) in the Flora of Iran. - Iran. J. Bot. 16: 130184.

Attar, F. and Mirtadzadini, M. 2009. Two new species of Cousinia Cass. Sect. Pugioniferae Bunge
(Asteraceae, Cardueae) from east and southeast of Iran. - Iran. J. Bot. 15: 146-152

Rechinger, K.H. 1972. Compositae, Cynareae I, Cousinia. - In: Rechinger, K.H. (ed.), Flora Iranica. Vol. 90. Akademische Druck- und Verlagsanstalt. Graz. 330 pp.

Rechinger, K.H. 1979. Compositae, Cynareae III, Cousinia. - In: Rechinger, K. H. (ed.), Flora Iranica. Vol. 139a. Akad. Druck- und Verlagsanstalt. 248 pp.

Tscherneva, O.V. 1962. Cousinia Cass. - In: Schischkin B. K. and Bobrov F.G. (eds.), Flora of the USSR. 27: $135-442$.

$$
* * * * *
$$

How to cite this article:

Attar, F., Mozaffarian, V. and Mirtadzadini, M. 2018.

Cousinia elymaitica (Cardueae, Asteraceae) a new species from west of Iran. - Nova Biol. Reperta 5 (3): 307-310. 